\title{
Imaging as a guide to tissue sampling
}

\author{
Leslie E Quint \\ From International Cancer Imaging Society (ICIS) 14th Annual Teaching Course \\ Heidelberg, Germany. 9-11 October 2014
}

When assessing a patient with lung cancer, it is important to stage the tumor in order to determine prognosis and direct appropriate therapy. Although imaging findings, particularly with CT and PET, can suggest the correct tumor stage, imaging is imperfect in this regard; enlarged and/or hypermetabolic lymph nodes may require sampling for confirmation of presumed tumor stage. A major role for imaging is to direct the most optimal method of tissue sampling in order to establish the highest possible tumor stage, so that proper therapy may be instituted [1]. Lymph node biopsies may be performed using mediastinoscopy for lymph nodes that are adjacent to the trachea or carina; bronchoscopy with endobronchial ultrasound for lymph nodes adjacent to the trachea, carina, mainstem bronchi and more peripheral airways; video assisted thoracoscopic surgery (VATS) for lesions adjacent to the pleural surfaces; Chamberlain procedure for lymph nodes in the aortopulmonary window and anterior paraaortic regions; endoscopic ultrasound (EUS) for nodes adjacent to the esophagus; ultrasonography for nodes in the neck and supraclavicular regions; and CT biopsy for large, accessible nodes. Selection of the best method for obtaining a tissue sample necessitates consideration of various factors, including the location of the lesion, the need for sampling of single vs. multiple lymph node stations, the amount of tissue that is necessary to make a confident diagnosis, the expected diagnostic yield and accuracy of the technique, the cost and availability of the procedure at the patient's institution, the expertise of the physicians, and the safety and risks involved.

Published: 9 October 2014

\section{Reference}

1. Quint LE: Multidisciplinary approach to thoracic tissue sampling. Cancer Imaging 2010, 10:S151-S155.

Correspondence: lequint@umich.edu

Department of Radiology, University of Michigan Health System, Ann Arbor, Ml 48109-5030 USA

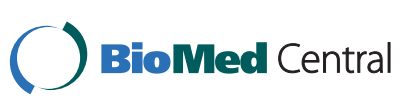

C 2014 Quint; licensee BioMed Central Ltd. This is an Open Access article distributed under the terms of the Creative Commons Attribution License (http://creativecommons.org/licenses/by/4.0), which permits unrestricted use, distribution, and reproduction in any medium, provided the original work is properly cited. The Creative Commons Public Domain Dedication waiver (http://creativecommons.org/publicdomain/zero/1.0/) applies to the data made available in this article, unless otherwise stated.
doi:10.1186/1470-7330-14-S1-07

Cite this article as: Quint: Imaging as a guide to tissue sampling. Cancer Imaging 2014 14(Suppl 1):07.
Submit your next manuscript to BioMed Central and take full advantage of:

- Convenient online submission

- Thorough peer review

- No space constraints or color figure charges

- Immediate publication on acceptance

- Inclusion in PubMed, CAS, Scopus and Google Scholar

- Research which is freely available for redistribution Submit your manuscript at
www.biomedcentral.com/submit C Biomed Central 